\title{
EVALUATING THE DETERMINANTS OF MARKET, EXCHANGE RATE AND INTEREST RATE RISKS IN THE PRE- AND POST FINANCIAL CRISIS FOR THE TURKISH BANKING INDUSTRY
}

\author{
Asst. Prof. İsmail Erkan ÇELIK \\ Doğuş University, FEAS, İstanbul, Turkey (erkancelik@dogus.edu.tr)
}

\begin{abstract}
This study investigates the bank specific determinants of market risk, exchange rate risk and interest rate risk (betas) over the whole period of 2002-2019, pre-crisis period of 20022008 and the post-crisis period of 2010-2019 for the Turkish banking sector. Using the two step approach, first the risk betas are estimated by employing $\operatorname{GARCH}(1,1)$ model with rolling window estimation and then, the bank specific determinants of each of these three different risk betas are determined by using panel data method. The results show that the interest rate and market beta is highly related to financial ratios compared to the exchange rate risk.
\end{abstract}

Keywords: Banking Sector, Market Risk, Exchange Rate Risk, Panel Data, Determinants of Beta, GARCH Model.

\section{FINANSAL KRIZ ÖNCESI VE SONRASI TÜRK BANKACILIK SEKTÖRÜNDE PIYASA, DÖVIZ KURU VE FAİZ ORANI RİSKLERININ BELIRLEYİCILERININN DEĞERLENDİRILMESİ}

\begin{abstract}
ÖZET
Bu çalışma bankalara özel de ğişkenlerin, piyasa riski, kur riski ve faiz oranı riskini (beta) üzerine etkilerini, Türk bankacılık sektörü açısından 2002-2019, 2002-2008 kriz öncesi ve 2010-2019 kriz sonrası dönemler için araştırmaktadır. İki aşamalı yaklaşımı kullanarak, önce risk betalarl, kayan pencereli GARCH $(1,1)$ modeli kullanılarak tahmin edilmiş ve ardından da, bu üç farklı risk betasının her birinin, bankaya özgü belirleyiciler tarafindan nasıl etkilendiği panel veri yöntemi kullanılarak incelenmiştir. Sonuçlar, faiz oranı ve piyasa risk betalarının, döviz kuru riskine klyasla, finansal oranlarla daha yüksek düzeyde ilişkili olduğunu göstermektedir.
\end{abstract}

Anahtar Kelimeler: Bankacılık Sektörü, Piyasa Riski, Kur Riski, Panel Data, Betanın Belirleyicileri, GARCH Model. 


\section{Introduction}

Understanding the determinants of bank risk factors is vitally important for banks to construct a reliable and consistent basis for their risk management policies and hence the stability of the financial system and the economy as a whole. The main risk factors that banks are exposed to can be enumerated as market risk, exchange rate risk and interest rate risk. Evidence on the determinants of risk provides valuable information for government policy makers responsible for the stability of the financial system, for portfolio managers attempting to minimize risks to maximize returns from their investment decisions, bank managers trying to achieve sustainable profitability of their banks. Thus, this study aims to investigate empirically the financial determinants of market, interest rate and exchange rate exposures (betas) of the Turkish banking institutions.

The Turkish banking sector has experienced radical changes in its structure following the 2001 financial crisis. During the 2001 crisis, 10 banks was transferred to the savings deposit insurance fund (SDIF). While the number of commercial banks in the sector was 61 in 2000 , it radically declined to 46 in 2001 . The number of commercial banks in the Turkish banking sector kept decreasing over time and it became 34 in 2005 and 33 in 2006. Later years the number of banks in the sector remained almost the same. During the 2009-2015 periods, there are total 33 commercial banks in the sector, 3 public, and 9 private, and 21 foreign commercial banks. It is worth to mention that the size of the most of the foreign banks is very small and they own only a few numbers of branches in Turkey. Measures aimed at strengthening the Turkish banking sector with the restructuring programme after 2001 crisis became successful and hence Turkey has achieved to establish one of the strongest banking sectors in the World. Quick recovery of the Turkish economy from the 2008 global financial crisis can be attributed to the well-structured Turkish banking sector. Although the Turkey still owns a well-functioning banking sector, the increased external debt of the sector has made banks vulnerable to foreign exchange risk.

There is a vast empirical literature on estimating the determinants of market beta which uses two-step approach. In the first step, market betas are estimated using Capital Asset Pricing model (CAPM) with ordinary least square (OLS) method in general. In the second step, beta coefficients obtained in the first step are defined as dependent variable and the determinants of betas are examined in cross section model. However, the recent empirical literature on the subject have shown that the basic CAPM model has some serious shortcomings (Fama \& French, 1992) and the nature of returns data can be best represented by the autoregressive conditional heteroscedasticity $(\mathrm{ARCH})$ type models which captures the dynamics of the relationship in estimating changing betas (Elyasi \& Mansur, 1998, 2003, 2005; Bae, 1990; Sehgal \& Agrawal, 2017; Agrawal \& Sehgal, 2018). Furthermore, the results from the empirical literature indicate that the size, sign and significance level of risk sensitivity coefficients differ across banks. For these reasons, recent empirical studies on the subject concentrate on estimation of risk sensitivity coefficients using ARCH type models using bank level data since the investigation of bank specific determinant of risk exposure differences among banks provides valuable information for policy makers and bank managers.

Furthermore, it is often argued that the risk perception of people has changed following the global financial crisis of 2008 due to developments in international financial markets, thereby 
sizes of market risk has changed. In particular, financial globalization is the underlying cause behind recent erratic changes in international financial markets. The empirical literature on the subject indicates that the effect of financial globalization and financial crisis on the stability of banking is closely related to the strength of domestic and international financial markets. Cordella \& Ospina Rojas (2017) argue that the impact of financial globalization on stability differs across time periods, countries and relative importance of domestic and international shocks: (i) Financial globalization intensifies volatility during the periods of high uncertainty and contributes to stabilize the returns in tranquil periods; (ii) Financial globalization plays a stabilizing role allowing for diversification opportunities and efficient risk sharing (Kose et al., 2009; Umutlu et al., 2010) for a country experiencing domestic shocks; however it increases instability in a country facing external shocks. Stiglitz (2004), Bae et al. (2004), Esqueda et al. (2012), however, argue that financial globalization may increase volatility and become a destabilizing factor in the economy.

Considering recent developments in the Turkish banking sector since the 2001 financial crisis, measuring the determinants of risk exposures of Turkish banking institutions are of utmost importance for the Banking Regulation and Supervision Agency (BRSA). The BRSA has established in 2000 to regulate banks towards coping with bank failures occurred in 2001 financial crisis. Although Turkey has achieved to build one of the strongest banking sector in the World by establishing new institutions, enacting new laws and introducing new regulation (Arabac1, 2018), close monitoring of the banking system is crucially important to sustain the stability of the banking system in the face of international and domestic economic developments such as global financial crisis, changing external debt of banks, inflation, interest and exchange rate rates. Furthermore, Kasman et al. (2011), Çiçek (2014) and Ekinci (2016) have recently shown that the GARCH model is the appropriate framework for modelling the Turkish bank stock returns rather than linear models which fails to capture time varying nature of returns data.

In the light of these discussions, this study examines the relationship between financial ratios and risk exposures (betas) of Turkish banking institutions using the two step approach. In the first step, market based measures of risk (betas) (market, interest rate and exchange rate risk exposures namely) will be estimated using $\operatorname{GARCH}(1,1)$ model for Turkish banking institutions. In the second step, the financial determinants of betas will be estimated using panel data model. In the model, betas calculated with 30 moving window in the first step will be defined as dependent variable and accounting based financial ratios obtained from banks balance sheets will be used as independent variables. The rest of the paper is organized as follows. Section 2 reviews the relevant empirical literature on the determinants of market beta. Section 3 introduces the data and methodology of the study. Section 4 provides estimation results. Section 4 concludes.

\section{Related Literature Review}

There is a vast empirical literature on estimating the effect of firm specific financial ratios on market based risk measures. The empirical methodology used in this literature involves the two-step approach: In the first step, market risk measure (beta) is estimated from the CAPM model and in the second step, the regression model in where market beta is dependent variable 
and accounting based financial ratios are independent variables are estimated. In this sense, the empirical literature on the subject is mainly focused on finding out accurate methods to estimate risk (betas) and choosing relevant dependent variables among many accounting financial ratios.

Early empirical studies employed ordinary least squares (OLS) method in estimating both market beta from CAPM model and the relationship between accounting variables and beta. They only differ in terms of choice of dependent variables used in the second step estimation. Some of these studies involve Jahankhani \& Lynge (1980), Mansur et al. (1993), Hassan (1993), Elyasiani et al. (1994), Berkowitz (1998), Schlueter \& Sivers (2014), and Mensah (1992). Dependent variables used in these studies vary significantly ${ }^{1}$.

There are also a significant number of empirical studies carried out using the same methodology for Turkish firms` data. Some of these studies are as follows. In an early study, Tanriöven \& Aksoy (2011) examine the determinants of systematic risk for eight sectors in ISE (Istanbul Stock Exchange) traded companies over the period 1997-2009 using regression method. They identified nine different accounting variables as determinants of market risk (beta). The results indicate that sales growth seems to have a significant effect on beta for all sectors except for food and technology sectors. The impact of the rest of the variables differs across sectors such as growth in assets affects beta in the metal sector, return on equity is effective in the paper-printing sector etc.

In a similar study, Er \& Kaya (2012) examine the relationship between the accounting variables and systematic risk using 28 stocks listed in Istanbul Stock Exchange over the period of 1.9.2007-31.12.2010. The results suggest that only one accounting variable; operating leverage (among current ratio, financial leverage interest coverage ratio, dividend payout ratio, asset size, book to market value, and growth accounting variables) has a significant effect on the CAPM's beta².

Karakus (2017) estimates the effect of accounting financial ratios on systematic risk of 58 companies listed in BIST-100 using panel data analysis for the period of 2006 and 2015. The results show that while profitability, eqity-debt ratio, cash ratio and debt ratio have significant and negative, size, turnover, lagged values of equity-debt and cash ratios have significant and positive effects on systematic risk. Furthermore, author reports that macroeconomic variables of consumer price index, gross domestic product per capita have negative effects on the dependant variable. In a similar study, Eryigit \& Eryigit (2009) also employ panel data analysis to examine the impact of accounting based financial ratios on systematic risk variables for Turkish companies listed in Borsa Istanbul. They found out that acid test ratio and asset turnover have positive and significant effect on systematic risk.

Uyar \& Çağlak $(2019)^{3}$ investigate the impact of financial ratios on systematic risk for 6 cement firms operating in 5 different countries and 16 firms operating in Turkey using panel

1 See Uyar \& Caglak (2019) for a detailed list of such variables.

2 Er \& Kaya (2012) and Karakus (2017) provide a good coverage of the early empirical literature on the determinants of beta for the Turkish financial markets

3 See Uyar \& Çăglak (2019) for the review of recent empirical literature on the relationship between financial beta coefficient and financial ratios for Turkish financial markets. 
data analysis for the period of 2007Q3-2017Q3. They have used 11 different financial ratios in their empirical analysis. found out that while return on equity and operation profit margin current ratios have a positive and significant effect on beta for Turkish cement firms, current ratio, asset turnover, logarithm of assets have a significant but negative effect on beta. Ercan et al. (2007) and Tepeli (2017) provide similar results. However, the estimation results for foreign cement firms return on assets and logarithm of sales are only significant variables.

However, the methodology followed in the early literature on the relationship between risk and accounting based financial ratios are heavily criticised for three reasons (Sehgal \& Agrawal, 2017; Agrawal \& Sehgal, 2018; Elyasiani \& Mansur, 1998, 2003, 2005). The first one is related to the use of the traditional CAPM model which is a single index market model. Many authors (Bae, 1990; Scott \& Peterson, 1986; Elyasiani \& Mansur, 2005; Choi et al., 1992) argue that bank returns must be best represented using a multi-index model rather than a single index CAPM model. The second one involves the use of linear regression model in estimating market based risk measures (betas). Since market based risk measures obtained from linear regression ignores the time-varying risk properties of the data, the risk measures obtained from OLS will be distorted, biased and inconsistent (Kasman et al., 2011; Elyasiani $\&$ Mansur, 2005). For this reason, recent studies employ ARCH type models to capture timevarying dynamics and volatility of data in estimation of market betas. Thirdly, recent studies on the subject use panel data of betas to determine the impact of financial ratios on risk measures (betas) rather than cross-section data. The former methodology accounts for dynamics and time-varying properties of risk measures of betas.

Elyasiani \& Mansur (2005) investigate the association between the market-based measures of risks for the 52 Japanese banking institutions using two-step approach over the period of 1986-1996. First, they used a multi-factor GARCH model to estimate the market, interest rate, and exchange rate risks betas and then estimate the determinants of these betas using OLS and ridge regression in terms of 13 different bank financial ratios such as cash due from banks, short-term investments, interest income, foreign exchange dominated assets etc. The results revealed that interest rate is only occasionally significant while market and exchange rate variables are significant for all the banks in the sample. Furthermore, although the types of financial ratios differ across bank risk factor, the financial ratios have the explanatory power of the market beta and exchange rate beta. Similar studies involves Ay Yong \& Taff (2007), Wong \& Leung (2009), Arora (2012, 2013), Sukcharoensin (2013), Sehgal \& Agrawal (2017), Agrawal \& Sehgal (2018).

The studies in Turkey mainly concentrate on measuring market risk, interest risk and exchange rate risk using ARCH type models. While Özçiçek (1997), Yamak et al. (2018) and Tokat (2013) investigated the impact of exchange rate on stock market price index, Demirhan \& Atış (2013) estimated the exchange rate exposure of textile and leather firms listed in Borsa Istanbul (BIST) using ARCH type models. Kasman et al. (2011) and Ekinci (2016) however examine the effects of changes in foreign exchange rate and interest rate on Turkish banks' returns using GARCH $(1,1)$ model. Gumrah \& Konuk (2018) employ the two-step approach to examine the determinants of risk factors for 12 Turkish banks listed in Borsa İstanbul. In the first step, they estimated time-varying betas using GARCH model for the period of 2001 and 2017. Then, they regress betas on trend, interest rate on treasury bills, consumer price index 
and volatility index. The results show that while the coefficients on treasury bill rates and trend variables are negative and significant coefficients, consumer prices seems to have positive effect and volatility has no effect on dependent variable beta.

Taken together, it can be argued that although a vast amount of empirical studies which use the Turkish data has been accumulated over time, only a limited number of these studies focused on estimation of risk measures (betas) for individual Turkish banks. Furthermore, these studies either estimate risk factors (betas) or estimate the determinants of betas lacking a proper method in estimation of betas. In this sense, the current study contributes to the empirical literature on Turkish banking in three ways. First, it aims to estimate both a various types of risk measures (market risk, interest rate risk and exchange rate risk) employing the methods that capture the time varying nature and volatility of bank returns. Second, it estimates the determinants of betas in the second step of the two-step approach using panel data estimation method. Third, it investigates whether the 2008 global financial crisis led to a change in risk perception of people in financial markets.

\section{The Methodology and the Data}

To examine the determinants of risk, this study adopts the two-step approach. In step one, market measures of risk, namely the market, interest rate and exchange rate risk betas, are estimated using a multivariate GARCH asset-pricing model for each bank. In step two, a model of determinants of risk measures is introduced in which market measures of risk appear as the dependent variable and accounting financial ratios are the independent variables. The model constructed in the second step is estimated using panel data analysis.

\subsection{Estimating the Market, Interest Rate and Exchange Rate Risk Betas}

The market, interest rate and exchange rate risk betas for individual banks are estimated employing the following multi-index GARCH $(1,1)$ model:

$$
\begin{aligned}
& R_{i t}=\beta_{i}+\beta_{i}^{M} M R_{t}+\beta_{i}^{E R} E R_{t}+\beta_{i}^{I R} I R_{t}+\delta \sqrt{h_{i t}}+\varepsilon_{i t} \\
& h_{i t}=\theta_{0}+\theta_{1} \varepsilon_{i t-1}^{2}+\theta_{2} h_{i t-1}
\end{aligned}
$$

where $R_{i t}$ is the return of bank $i$ at time $t ; \beta_{i}$ is the intercept term for bank $i ; I R_{t}$ is the unexpected change in interest rate; $E R_{t}$ is the unexpected change in exchange rate; $M R_{t}$ is the return on the Turkish market index (BIST100); $h_{i t}$ is the conditional variance of bank returns; $\varepsilon_{i t}$ is the error term. The parameters $\beta_{i}^{M}, \beta_{i}^{E R}$ and $\beta_{i}^{I R}$ are the coefficients of the market index, interest rate index, and foreign exchange index, respectively, and proxy the systematic market risk, interest rate risk and foreign exchange risk. In the variance equation (2), $\theta_{0}$ is the constant, $\theta_{1}$ and $\theta_{0}$ are the $\mathrm{ARCH}$ and GARCH terms respectively.

The variables given in Equation (1) are obtained and calculated from the Finnet Data Delivery System for a sample of seven Turkish commercial bank stocks listed on the Borsa Istanbul $(\mathrm{BIST})^{4}$. It is daily data cover the period of 02.01 .2002 to 30.04 .2019 with 4355 observations

4 In order to have a balanced panel dataset, the sample is composed of the banks that have continuous data over the sample period. 
due to data availability. The bank return variable is calculated as logarithmic difference of $R_{i t}$, which is the closing price of bank $i$ 's index at time $t$. That is, $R_{i t}=\ln \left(R_{i t} / R_{i t-1}\right)$.

The interest rate risk $\left(I R_{t}\right)$ and the exchange rate risk $\left(E R_{t}\right)$ variables are calculated as unexpected changes in interest rate and exchange rate using the autoregressive integrated moving average (ARIMA) model. The interest rate is measured as the 2-year Turkish government bond yield and the foreign exchange rate is defined as equally weighted average of the US dollar and the Euro. The residuals obtained from the ARIMA models ${ }^{5}$ chosen based on the Akaike Information Criteria (AIC) are used as a proxy for the unexpected changes in interest rates and exchange rates ${ }^{6}$.

The GARCH $(1,1)$ model given in Equations (1) and (2), are then estimated on a fixed 252 estimation window, rolling 252 days every time. This procedure is followed for mainly two reasons. First, the structure of financial markets has changed due to recent developments in global and domestic markets. The global financial crisis of 2008 and globalization of financial markets have affected the risk perception of people and sizes of market risk by making international financial markets more volatile. The structure of the Turkish financial markets has also changed through establishing new institutions, enacting new laws and introducing new regulation in financial sector since the 2001 financial crisis. In summary, recent domestic and global developments made economies more volatile and changed the structure of these economies. Granger (1996) considers structural changes as one of the most important problems in empirical analysis. The second reason for adopting rolling window estimation of size 252 days is to obtain annual estimates for beta coefficients, which are going to be used as a dependent variable in panel data analysis in step-two. In sum, to handle structural change and changing parameters problems, the GARCH $(1,1)$ model is estimated using a fixed rolling window estimation of size 252 days. Hence the estimates of each of the parameters (betas) in equation (1) vary for each window. For the sample period at hand, fixed windows of size 252 days means that 16 different sets of parameters will be estimated for each risk betas.

Furthermore, the estimation of the GARCH $(1,1)$ model with 252 days rolling window is carried out for whole sample period of 02.01.2002 to 30.04 .2019 , for pre-crisis period of 02.01.2002 to 29.09.2008 and for post-crisis period of 01.04 .2009 to $30.04 .2019^{7}$.

Table 1 presents the descriptive statistics for market, interest rate and exchange rate risk betas obtained from the estimation of the GARCH $(1,1)$ model given in Equations (1) and (2) using a 252 day estimation rolling window. Examination of the Table 1 shows that mean and median values of risk betas seem to be very close to each other confirming that there is no danger of outlier problem in the sample. However, minimum and maximum values of risk betas differ significantly indicating that the sized of risk betas are changing vastly over time and across

5 For the whole sample period, ARIMA $(4,1,4)$ is chosen for the exchange rate and ARIMA $(9,1,4)$ for the interest rate. For pre-crisis period, $\operatorname{ARIMA}(5,1,3)$ is chosen for the exchange rate and $\operatorname{ARIMA}(7,1,2)$ for the interest rate. For post-crisis period, $\operatorname{ARIMA}(8,1,3)$ is chosen for the exchange rate and $\operatorname{ARIMA}(7,1,3)$ for the interest rate.

6 See Celik (2019) for more information about using the ARIMA models to measure unexpected interest rate and exchange rate variables.

7 See Sehgal \& Agrawal (2017) for detailed discussion about the choice of crisis periods. 
banks. The skewness measures are systematically different from zero indicating that market, interest rate and exchange rate risk betas have non-symmetric distribution. While skewness statistic is negative for market and interest rate risk betas, it is positive for the exchange rate beta for the sample, pre and post-crisis periods. The kurtosis statistic exceeds the normal value of three implying that the underlying data are highly leptokurtic with fat-tails compared to the Gaussian distribution. The Jarque-Bera statistic has been rejected for all risk betas at one percent level of significance indicating that all betas are changing rapidly in an unpredictable way (Olugbode et al., 2014).

Table 1: Descriptive Statistics for Market Risk, Exchange Rate Risk and Interest Rate Risk Betas

\begin{tabular}{|c|c|c|c|c|c|c|c|c|c|}
\hline & \multicolumn{3}{|c|}{$\begin{array}{c}\text { Sample period } \\
(2003-2018)\end{array}$} & \multicolumn{3}{|c|}{$\begin{array}{c}\text { Pre-crisis period } \\
(2003-2008)\end{array}$} & \multicolumn{3}{|c|}{$\begin{array}{c}\text { Post-crisis period } \\
(2010-2018)\end{array}$} \\
\hline & $\beta^{M}$ & $\beta^{E R}$ & $\beta^{I R}$ & $\beta^{M}$ & $\beta^{E R}$ & $\beta^{I R}$ & $\beta^{M}$ & $\beta^{E R}$ & $\beta^{I R}$ \\
\hline Mean & 1.0636 & 0.0412 & -0.0198 & 1.0543 & 0.0108 & -0.0217 & 1.0608 & 0.0484 & -0.0206 \\
\hline Median & 1.1665 & 0.0375 & -0.0120 & 1.1275 & 0.0334 & 0.0074 & 1.2011 & 0.0256 & -0.0157 \\
\hline Maximum & 1.5244 & 0.7104 & 0.2687 & 1.4916 & 0.7104 & 0.2687 & 1.5500 & 0.7785 & 0.2078 \\
\hline Minimum & -0.1052 & -0.610 & -0.4192 & -0.1052 & -0.4527 & -0.4192 & -0.1387 & -0.3674 & -0.2712 \\
\hline Std. Dev. & 0.3219 & 0.2075 & 0.1174 & 0.3113 & 0.2126 & 0.1474 & 0.3582 & 0.1970 & 0.0867 \\
\hline Skewness & -1.0661 & 0.2870 & -0.6131 & -1.6384 & 0.7996 & -0.7574 & -1.0388 & 1.0957 & -0.4002 \\
\hline Kurtosis & 3.8815 & 4.4323 & 4.0528 & 6.6907 & 5.0992 & 3.4606 & 3.6476 & 5.7037 & 4.4662 \\
\hline Jarque-Bera & $24.84 *$ & $11.11^{*}$ & $12.19 *$ & $35.52 *$ & $10.16^{*}$ & 3.656 & $12.43^{*}$ & $31.80 *$ & $7.330 * *$ \\
\hline Observations & 112 & 112 & 112 & 35 & 35 & 35 & 63 & 63 & 63 \\
\hline
\end{tabular}

Notes: $\beta^{M}, \beta^{E R}$ and $\beta^{I R}$, represent market risk, exchange rate risk, interest rate risk betas, respectively. *, ** indicate the significance level at $1 \%$ and $5 \%$ respectively.

\subsection{Modelling the Determinants of Market, Interest Rate and Foreign Exchange Risk}

Having reviewed empirical literature on the determinants of market measures of risk in Section 2, we see that there is no consensus over which explanatory variables to use in the empirical model. Considering the explanatory variables used frequently in the literature (Topak \& Talu, 2017; Elyasani \& Mansur, 2015; Sehgal \& Agrawal, 2017; Uyar \& Caglak, 2019; Karakus, 2017; Gumrah \& Konuk, 2018), this section introduces the empirical model of the determinants of market, interest rate and foreign exchange risk employed in this study. The empirical model of the determinants of market based measures of risk betas used in this study is formulated as:

$$
\begin{aligned}
& \beta_{i t}^{j}=\alpha_{0 i}+\alpha_{1} C A P+\alpha_{2} C R R+\alpha_{3} N P L+\alpha_{4} D I V+\alpha_{5} F E A+ \\
& \alpha_{6} F E L+\alpha_{7} N I M+\alpha_{8} L Q R+\alpha_{9} R O A+\alpha_{10} S E C+\alpha_{11} S I Z E+\varepsilon_{i t}
\end{aligned}
$$

where $\beta_{i t}^{j}$ represents the market measures of risk betas for bank $i$ at time $t$ obtained from estimating the GARCH $(1,1)$ model given in Equations (1) and (2) above with rolling 
window; $\alpha_{0 i}$ is constant term for bank $i$; and $j$ represents market risk, foreign exchange risk and interest rate risk respectively. $\varepsilon_{i t}$ is error term for bank $i$ at time $t$. CAP is a proxy for capital adequacy and calculated as the ratio of equity to total assets; $C R R$ represents credit risk and measured by dividing total loans to total assets; $N P L$ is the ratio of non-performing loans to total assets; $D I V$ is the ratio of non-interest income to total assets; $F E A$ is the share of foreign exchange dominated assets in total assets; FEL is the ratio of foreign exchange dominated liabilities to total assets; NIM represents management efficiency and is measured by dividing net interest margin by total assets; $L Q R$ is a proxy for liquidity risk which is equal to loans to deposits ratio; $R O A$ is the ratio of profits to assets which proxies overall profitability; $S E C$ is the ratio of investment in securities to total assets; $S I Z E$ is measured by dividing total assets of a bank $i$ by total assets of banking sector in Borsa Istanbul.

The data related to the explanatory variables in Equation (3) are obtained and calculated from the Finnet Data Delivery System for a sample of seven Turkish commercial bank stocks listed on the Borsa Istanbul (BIST). These commercial banks include Akbank, Granti bank, ICBC bank, Is bank, Qnbf bank, Seker bank and Yapı Kredi banks namely. It is annual data obtained from banks' balance sheets over the period of 2003 to 2018. The dataset is also divided into two sub-periods: pre-crisis period of 2003 to 2008 and the post-crisis period of 2010 to 2018 .

\section{Empirical Findings}

This section provides the results obtained from estimating the model of the bank specific determinants of market, interest rate and exchange rate risk betas given in Equation (3) using the two-step approach. The two-step approach involves estimating risk betas in the first step and estimating the beta model of Equation (3) using risk betas as dependent variable and accounting financial ratios as independent variable in the second step.

\subsection{Findings on the Estimates of Market, Interest Rate and Exchange Rate Risk Betas}

Appendix Tables 1A to $3 \mathrm{~A}$ presents the parameter estimates of market, interest rate and exchange rate risk betas employing the GARCH $(1,1)$ model. As mentioned above, the GARCH-type methods with rolling window estimation provide better proxies for market based risk measures since they are able to handle structural change and volatility in the series and to capture the time-varying properties of the series in the presence of clustering of observations. Appendix Tables 1A to $3 \mathrm{~A}$ present estimated beta coefficients for the market, interest rate, and exchange rate in the mean equation along with the variance equation the ARCH and GARCH coefficients $^{8}$. The results in Table 1A indicate that all market beta values are positive and statistically significant at the $1 \%$ level ranging from 0.73 to 1.34 . Similarly, the interest rate betas are negative for all banks except for Akbank and statistically significant for 5 banks (about 70\% of banks) contrary to the findings of Kasman et al. (2011) and Ekinci (2016), who report largely insignificant interest rate betas within the context of multivariate GARCH model

8 This section concentrates on the interpretation of risk coefficients in the mean equation since the GARCH model plays a subsidiary role of estimating the market based risk betas in this paper. Please see, among other, Elyasani \& Mansur (2015), Kasman et al. (2011), Olugbode et al. (2014), Celik (2019) for interpretation of the coefficients of variance equation in the GARCH model. 
for Turkish banks. However, it is worth mentioning that the exchange rate beta is found to be positive and significant for only one bank. Furthermore, the coefficient estimates of variance equation are found to be positive and statistically significant for all cases. The sum of the $\operatorname{ARCH}\left(\alpha_{1}\right)$ and the GARCH $\left(\alpha_{2}\right)$ coefficients is less than unity but they are close to one for all cases, indicating model stability and high persistence of shocks. In sum, the results in Table 1A indicate that while the market risk and interest rate risk is important for Turkish bank over the period of 2002 to 2019 , the exchange rate risk beta seems to be insignificant in almost all cases.

However, the findings on the risk exposure of the Turkish banks in Table 1A change drastically once we examine the estimates of risk betas for sub-periods, for the pre-crisis period of 2002-2008 and post-crisis period of 2009-2019 namely. The coefficient estimates of market, interest rate and exchange rate risk betas for the pre and post-crisis periods are presented in Tables 2A and Table 3A respectively. Examination of the Tables shows that all market beta estimates are positive and statistically significant for both pre and post-crisis periods. However, the range of the market beta values seems to have increased significantly in the post-crisis period (ranging from 0.61 to 1.38 ) compared to pre-crisis period (ranging from 0.89 to 1.28). Similarly, the results also indicate that there is a striking increase in the interest rate and exchange risks in the post-crisis period compared to pre-crisis period. While the interest rate beta estimates are significant for only two banks, one of which has a positive and the other has a negative sign, they are negative and statistically significant for four banks. The findings in Table 2A shows that only two banks were positively and significantly exposed to exchange rate risk during the pre-crisis period. In the post-crisis period, the number of banks exposed to the exchange rate risk has increased to four, two of which have positive and statistically significant and two of which have negative and statistically significant exchange rate risk coefficients. As in Table 1A, the coefficient estimates of variance equations in Tables $2 \mathrm{~A}$ and $3 \mathrm{~A}$ are positive and statistically significant and the sum of the $\operatorname{ARCH}\left(\alpha_{1}\right)$ and the GARCH $\left(\alpha_{2}\right)$ coefficients is less than unity but close to one for all cases indicating the stability models and high persistence of shocks in sub-periods. Taken together the results presented in Tables $1 \mathrm{~A}$ to $3 \mathrm{~A}$, we understand that the market, interest rate and exchange rate risk coefficients seem to be changing over time implying the importance of structural change and changing coefficients problems in modelling the determinants of risk in Turkish banking industry.

\subsection{Estimating the Determinants of the Market Risk, Interest Rate Risk and Exchange Rate Risk Betas Models}

Having established that the structure of the GARCH $(1,1)$ model and risk betas are changing over time, the beta coefficients estimates are produced by estimating the GARCH $(1,1)$ model using a fixed rolling window estimation of size 252 days over the sample period. Then these beta estimates are used in the estimation of the beta risk models given in Equation (3) as dependent variable and bank specific decision variables as independent variable. The beta risk models of Equation (3) are estimated using fixed effect panel data estimator.

Table 2 presents the results of the paned data estimation for the market, exchange rate and interest betas for the period of 2003-2018. The R-square value of 0.74 for the market beta model indicates a relatively good fit for the model. However, the R-square values are only 0.08 
and 0.24 for the exchange rate risk and interest rate risk. Examination of Tables 3 and 4 indicate that for the latter models, the R-square values get higher for the pre- and post-crisis periods.

Examination of the Table 2 indicates that the coefficients of capital adequacy (CAP), non-performing loans (NPL), diversification (DIV), and net interest margin (NIM) variables are all found to be statistically significant in the market beta model. The sign for the significant variables of CAP, DIV and NIM are consistent for expectations. While the coefficients of capital adequacy (CAP) and diversification (DIV) variables are assigned positive sings, a negative signs are obtained form the non-interest income (NIM) and non-performing loans (NPL) variables. A positive sign on capital adequacy (CAP) indicates that an increase in equity leads to an increase in opportunity cost of capital and hence increase market beta since cost of equity is greater than cost of borrowing. The ratio of non-interest income to total assets is interpreted as an indicator of diversification (DIV). A positive sign on non-interest income (DIV) implies that diversification (DIV) increases market risk. This occurs if the market believes that an increase in non-interest income will be used for speculation rather than risk hedging. The ratio of net interest margin to total assets (NIM) can be used as a proxy for management efficiency. The negative sign on management efficiency (NIM) variable has a direct interpretation as an increase in NIM leads to higher profits and hence reduce market risk. However, the nonperforming loans (NPL) seem to have a negative significant impact on market risk. This result comes as a surprise since an increase in the share of non-performing loans in total loans indicate an increase in the share of uncollectible loans in total loans and decrease in profits.

The third column of Table 2 presents estimates of the exchange rate beta model. The empirical results reveal that non-performing loan (NPL) affects the exchange rate beta positively as expected, while no other accounting variables are found to be significant. The insignificance of financial ratios in the exchange rate beta model may have different implications. First, it may imply that accounting variables do not contain much information about foreign exchange risk that banks exposed to. If this is the case, then it can be argued that using exchange rate risk as a base for decision making may be misleading (Elyasiani \& Mansur, 2005). Second, exchange rate risk that banks face is minimized through efficient banking regulations.

The estimates of the interest rate beta model are provided in the fourth column of Table 2. The findings show that while the capital adequacy (CAP) and foreign exchange dominated liabilities (FEL) variables have positive and statistically significant effect, the credit risk (CRR), profitability (ROA) and foreign exchange dominated assets (FEA) variables have statistically significant and negative effects on interest rate risk beta. The positive sing on the coefficient of capital adequacy (CAP) variable may seem confusing since capital adequacy is an indicator of capital strength of a bank and as this ratio increases, it is expected that the risk of insolvency decreases thereby decreasing cost of funding. However, increase in capital adequacy may increase interest rate risk for two reasons: First, increase in the ratio of equity to total assets may increase cost of equity due to an increase in the opportunity cost of capital. Second, increases in capital adequacy may lead banks to borrow less thereby decreasing benefits from tax subsidies and hence increase the overall cost of funding ${ }^{9}$. The interpretation of negative sign on the coefficient of credit risk (CRR) and profitability (ROA) variables are

9 See Topak \& Talu (2017) for capital adequacy-risk relationship. 
straightforward. Since credit risk measured as total loans to total assets has a positive effect on profit, it will have a negative effect on interest rate beta. Similarly we expect that interest rate risk decreases when profitability (ROA) increases since profitability of banks increases with increasing macroeconomic performance of economy. Interestingly, the results reveal a close connection between assets and liabilities in foreign currency and interest rate risk. As the ratio of foreign exchange dominated assets to total assets (FEA) increase, interest rate risk decrease in particularly when exchange rate is volatile. As this ratio (FEA) gets higher, increase in exchange rate further increases bank profits in domestic currency thereby decrease interest rate risk. The positive coefficient of the ratio of foreign exchange dominated liabilities to total assets (FEL) can be interpreted in the same way.

Table 2: Bank Specific Determinants of Market Risk, Exchange Rate Risk and Interest Rate Risk, 2003-2018

\begin{tabular}{|c|c|c|c|}
\hline $\begin{array}{l}\text { Explanatory } \\
\text { variables }\end{array}$ & $\begin{array}{c}\text { Market risk } \\
\beta^{M}\end{array}$ & $\begin{array}{c}\text { Exchange rate risk } \\
\beta^{E R}\end{array}$ & $\underset{\beta^{I R}}{\text { Interest rate risk }}$ \\
\hline$C A P$ & $0.0351 *(0.0089)$ & $-0.0032(0.0089)$ & $0.0073 * * *(0.0046)$ \\
\hline$C R R$ & $0.0008(0.0032)$ & $-0.0024(0.0033)$ & $-0.0050 *(0.0017)$ \\
\hline$N P L$ & $-0.0338 *(0.0085)$ & $0.0182 * * *(0.0091)$ & $-0.0053(0.0047)$ \\
\hline$D I V$ & $0.0261 * *(0.0121)$ & $-0.0093(0.0130)$ & $0.0056(0.0067)$ \\
\hline$F E A$ & $0.0065(0.0058)$ & $0.0054(0.0056)$ & $-0.0056^{*}(0.0029)$ \\
\hline$F E L$ & $-0.0044(0.0054)$ & $-0.0055(0.0052)$ & $0.0081 * * *(0.0027)$ \\
\hline$N I M$ & $-0.0347 * * *(0.0207)$ & $0.0206(0.0236)$ & $-0.0021(0.0121)$ \\
\hline$L Q R$ & $-0.0017(0.0013)$ & $0.0017(0.0014)$ & $0.0001(0.0007)$ \\
\hline$R O A$ & $-0.0040(0.0164)$ & $0.0002(0.0174)$ & $-0.0143 * * *(0.0090)$ \\
\hline SEC & $-0.0031(0.0035)$ & $-0.0015(0.0036)$ & $-0.0012(0.0019)$ \\
\hline$S I Z E$ & $-1.0223(1.5769)$ & $-0.3098(0.4046)$ & $0.1590(0.2081)$ \\
\hline CONS & $0.9212 *(0.3380)$ & $0.0414(0.2851)$ & $0.0538(0.1466)$ \\
\hline DUM5 & $-0.9040 *(0.1895)$ & $0.0738(0.2222)$ & $0.1746 * * *(0.1143)$ \\
\hline$R^{2}$ & 0.7427 & 0.0833 & 0.2433 \\
\hline$F$-statistic & $14.911 *$ & 0.7501 & $2.652 *$ \\
\hline$D W$ & 1.6069 & 2.0337 & 2.3842 \\
\hline
\end{tabular}

Notes: Coefficients refer to the estimates of the following risk model:

$\beta_{i t}^{j}=\alpha_{0 i}+\alpha_{1} C A P+\alpha_{2} C R R+\alpha_{3} N P L+\alpha_{4} D I V+\alpha_{5} F E A+\alpha_{6} F E L+\alpha_{7} N I M+\alpha_{8} L Q R+\alpha_{9} R O A+\alpha_{10} S E C+\alpha_{11} S I Z E+\varepsilon_{i t}$

Variable definitions are provided in the text. Values in parenthesis are standard errors. $*$, $* *, * * *$ indicate the significance level at $1 \%, 5 \%$ and $10 \%$ respectively. $R^{2}$ is the square of multiple correlation coefficient, $D U M$ is a dummy variable takes 1 for the bank 5 in 2009, and $D W$ is Durbin-Watson Statistic. 
Table 3 provide the estimates pertaining to the determinants of risk models in pre and post crisis periods. Taken together, comparison of the results provided in Tables 2 and 3 provides valuable insights into the relationship between risk measures and financial ratios for the Turkish banking sector. Firstly, the number and the type of determinants of risk measures differ significantly across the whole sample, pre-crisis and post-crisis time periods. The variables that have statistically significant effect on market risk are the CAP, NPL, DIV and NIM variables for the whole period, they are the NPL, DIV, FEA, FEL and SIZE variables for the pre-crisis period and they are the DIV and FEL variables for the post-crisis period. Similarly, the determinants of interest rate beta seem to have changed significantly ${ }^{10}$. However, the determinants of exchange rate beta seem to stay the same except for the pre-crisis period. In the post-crisis period, the CRR and ROA variables have a significant impact on exchange rate risk rather than the NPL variable.

Secondly, the results indicate that the interest rate beta is highly related to accounting variables compared to other risk betas. This implies that accounting variables contain valuable information about interest rate exposure of Turkish banks and therefore, bank managers can use accounting variables to develop policies to cope with interest rate risk. The empirical findings given in Table 2 and 3 indicate that while the effect of foreign currency (the FEA and FEL variables) and profitability on interest rate risk have disappeared, the diversification (DIV), management efficiency (NIM), liquidity risk (LQR), the size of operations (SIZE), credit risk (CRR) begin to determine the interest rate risk in the post-crisis period.

Thirdly, contrary to the public opinion that foreign exchange risk exposure has increased in the post-crisis period, the results presented in this study indicate that exchange rate risk is not an important risk factor for the Turkish banks and it is not associated with a large number of accounting variables of these banks. The only accounting variable that has an impact on exchange rate beta is non-performing loans (NPL) for the whole period and pre-crisis period. In the post-crisis period, the profitability (ROA) and credit risk (CRR) variables have statistically significant effect on exchange rate risk. Caution is in order for these rather surprising findings. The results might be related to the use of unexpected exchange rate changes in estimation of foreign exchange risk beta.

10 While the significant determinants of interest rate beta involve the CAP, CRR, FEA, FEL and ROA variables for the whole period, they become the CRR, DIV, NIM, LQR and SIZE variables for the post-crisis period and the CRR, FEA, FEL and ROA for the pre-crisis period. 
Table 3: Bank Specific Determinants of Market Risk, Exchange Rate Risk and Interest Rate Risk, the Pre- and Post-Crisis Periods

\begin{tabular}{|c|c|c|c|c|c|c|}
\hline \multirow[b]{2}{*}{$\begin{array}{l}\text { Explanatory } \\
\text { variables }\end{array}$} & \multicolumn{3}{|c|}{ Pre-Crisis Period, 2003-2008 } & \multicolumn{3}{|c|}{ Post-Crisis Period, 2010-2018 } \\
\hline & $\begin{array}{c}\text { Market } \\
\text { risk } \\
\beta^{M}\end{array}$ & $\begin{array}{c}\text { Exchange } \\
\text { rate risk } \\
\beta^{E R}\end{array}$ & $\begin{array}{c}\text { Interest } \\
\text { rate risk } \\
\beta^{I R}\end{array}$ & $\begin{array}{c}\text { Market } \\
\text { risk } \\
\beta^{M}\end{array}$ & $\begin{array}{c}\text { Exchange } \\
\text { rate risk } \\
\beta^{E R}\end{array}$ & $\begin{array}{c}\text { Interest } \\
\text { rate risk } \\
\beta^{I R}\end{array}$ \\
\hline$C A P$ & $\begin{array}{c}0.0217 \\
(0.0157)\end{array}$ & $\begin{array}{l}-0.0138 \\
(0.0178)\end{array}$ & $\begin{array}{l}-0.0118 \\
(0.0137)\end{array}$ & $\begin{array}{l}-0.0039 \\
(0.0374)\end{array}$ & $\begin{array}{c}0.0706 \\
(0.0395) \\
\end{array}$ & $\begin{array}{c}0.0027 \\
(0.0066)\end{array}$ \\
\hline$C R R$ & $\begin{array}{l}-0.0168 \\
(0.0135)\end{array}$ & $\begin{array}{l}-0.0014 \\
(0.0153)\end{array}$ & $\begin{array}{l}-0.026 * * \\
(0.0123)\end{array}$ & $\begin{array}{c}0.0028 \\
(0.0072)\end{array}$ & $\begin{array}{c}-0.0204 * * \\
(0.0098)\end{array}$ & $\begin{array}{l}-0.0049 * \\
(0.0024)\end{array}$ \\
\hline$N P L$ & $\begin{array}{c}-0.0304 * \\
(0.0110)\end{array}$ & $\begin{array}{c}0.0213 * * * \\
(0.0125)\end{array}$ & $\begin{array}{l}-0.0133 \\
(0.0094)\end{array}$ & $\begin{array}{l}-0.0229 \\
(0.0249)\end{array}$ & $\begin{array}{c}0.0100 \\
(0.0398)\end{array}$ & $\begin{array}{l}0.00001 \\
(0.0095)\end{array}$ \\
\hline$D I V$ & $\begin{array}{l}0.0624^{*} \\
(0.0182)\end{array}$ & $\begin{array}{l}-0.0100 \\
(0.0206)\end{array}$ & $\begin{array}{l}-0.0225 \\
(0.0159)\end{array}$ & $\begin{array}{l}-0.0956^{*} \\
(0.0396)\end{array}$ & $\begin{array}{c}0.0001 \\
(0.0432)\end{array}$ & $\begin{array}{c}-0.0325 * * \\
(0.0167)\end{array}$ \\
\hline FEA & $\begin{array}{l}0.0462 * \\
(0.0123)\end{array}$ & $\begin{array}{c}0.0114 \\
(0.0139) \\
\end{array}$ & $\begin{array}{l}-0.022 * * \\
(0.0098)\end{array}$ & $\begin{array}{l}-0.0001 \\
(0.0120)\end{array}$ & $\begin{array}{c}0.0152 \\
(0.0140) \\
\end{array}$ & $\begin{array}{l}-0.0046 \\
(0.0036)\end{array}$ \\
\hline$F E L$ & $\begin{array}{c}-0.0401 * \\
(0.0115)\end{array}$ & $\begin{array}{l}-0.0130 \\
(0.0131)\end{array}$ & $\begin{array}{l}0.0270 * \\
(0.0088)\end{array}$ & $\begin{array}{c}-0.0215 * * \\
(0.0098)\end{array}$ & $\begin{array}{l}-0.0020 \\
(0.0114) \\
\end{array}$ & $\begin{array}{c}0.0001 \\
(0.0035)\end{array}$ \\
\hline NIM & $\begin{array}{l}-0.0788 \\
(0.0295)\end{array}$ & $\begin{array}{c}0.0260 \\
(0.0335)\end{array}$ & $\begin{array}{c}0.0365 \\
(0.0233)\end{array}$ & $\begin{array}{c}0.0467 \\
(0.0789)\end{array}$ & $\begin{array}{l}-0.0986 \\
(0.1003)\end{array}$ & $\begin{array}{c}0.0442 * * * \\
(0.0257)\end{array}$ \\
\hline$L Q R$ & $\begin{array}{c}0.0073 \\
(0.0051)\end{array}$ & $\begin{array}{l}-0.0001 \\
(0.0058)\end{array}$ & $\begin{array}{c}0.0050 \\
(0.0040)\end{array}$ & $\begin{array}{l}-0.0020 \\
(0.0018)\end{array}$ & $\begin{array}{l}-0.0025 \\
(0.0021)\end{array}$ & $\begin{array}{c}0.0018 * * \\
(0.0008)\end{array}$ \\
\hline$R O A$ & $\begin{array}{l}-0.0066 \\
(0.0195) \\
\end{array}$ & $\begin{array}{l}-0.0023 \\
(0.0221)\end{array}$ & $\begin{array}{c}-0.048 * * * \\
(0.0257)\end{array}$ & $\begin{array}{c}0.0343 \\
(0.0599) \\
\end{array}$ & $\begin{array}{c}0.1190 * * * \\
(0.0664)\end{array}$ & $\begin{array}{c}0.0053 \\
(0.0252) \\
\end{array}$ \\
\hline$S E C$ & $\begin{array}{l}-0.0025 \\
(0.0047)\end{array}$ & $\begin{array}{l}-0.0055 \\
(0.0053)\end{array}$ & $\begin{array}{l}-0.0028 \\
(0.0052)\end{array}$ & $\begin{array}{c}0.0131 \\
(0.0104)\end{array}$ & $\begin{array}{l}-0.0103 \\
(0.0107)\end{array}$ & $\begin{array}{l}-0.0021 \\
(0.0044)\end{array}$ \\
\hline$S I Z E$ & $\begin{array}{c}1.116 * * * \\
(0.6667)\end{array}$ & $\begin{array}{c}-0.7038 \\
(0.7578)\end{array}$ & $\begin{array}{c}-1.3667 \\
(2.5107) \\
\end{array}$ & $\begin{array}{l}-5.6520 \\
(4.8676)\end{array}$ & $\begin{array}{l}-2.0755 \\
(5.1835)\end{array}$ & $\begin{array}{c}0.456^{* * * *} \\
(0.2823)\end{array}$ \\
\hline CONS & $\begin{array}{c}0.7490 \\
(0.5917)\end{array}$ & $\begin{array}{c}0.3095 \\
(0.6726)\end{array}$ & $\begin{array}{c}1.2780 * * \\
(0.7178)\end{array}$ & $\begin{array}{c}3.0928 * * \\
(1.3484)\end{array}$ & $\begin{array}{c}0.7266 \\
(1.5700) \\
\end{array}$ & $\begin{array}{c}0.2430 \\
(0.2413) \\
\end{array}$ \\
\hline$R^{2}$ & 0.7598 & 0.3347 & 0.7053 & 0.8181 & 0.5692 & 0.3143 \\
\hline$F$-stat & $6.6136^{*}$ & 1.0520 & $2.3938^{* *}$ & $11.9049 *$ & $1.9553 * *$ & $2.125^{* *}$ \\
\hline$D W$ & 2.3118 & 2.5152 & 2.8069 & 1.9760 & 2.1239 & 2.2826 \\
\hline
\end{tabular}

Notes: See notes in Table 2.

Fourthly, the number of significant determinants of market risk has declined from five in the pre-crisis period to two in the post-crisis period. While the NPL, DIV, FEA, FEL and SIZE variables have statistically significant effect on market beta in the pre-crisis period, the diversification (DIV) and foreign exchange dominated liabilities (FEL) variables have statistically significant coefficients in the post-crisis period. Importantly, the sign of 
diversification (DIV) variable was positive in the pre-crisis period and it has changed to negative. As mentioned above, the diversification variable is defined as the ratio of non-interest income to total assets and it may have a positive or negative coefficient. If the sign of diversification variable is positive, the market believes that an increase in non-interest income will be used for speculation rather than risk hedging. For this reason, the negative sign observed in the postcrisis period imply that the market sees an increase in non-interest income to be used in risk hedging and hence the diversification (DIV) reduces the market risk beta.

Fifthly, empirical findings of this paper provide additional evidence to the argument that the 2008 global financial crisis has radically changed the risk perception of the people and the structure of international markets radically. In particular, the empirical studies on the determinants of risk should be very careful about the consequences of developments following the financial crisis. In this sense, the empirical studies on the subject should use methodologies to handle the time varying nature of risk data, structural change and changing coefficients problems.

\section{Conclusion}

This study empirically examined the relationship between accounting based bank specific financial ratios and market, interest rate and exchange rate risk measures for the Turkish banking industry employing two-step approach. In the first step, market based risk measures are estimated by using the GARCH $(1,1)$ model with rolling window estimation. Then using risk measures obtained in the first step as dependent variable and accounting bank specific financial ratios as independent variables, the fixed effect panel data risk models are estimated for the period of 2002-2019, for the pre-crisis period of 2002-2008 and for the post-crisis period of 2009-2019.

The results provide a number of important information about the determinants of market, interest rate and exchange rate risk. First, the market, interest rate and exchange rate risk coefficients seem to be changing over time implying the importance of structural change and changing coefficients problems in modelling the determinants of risk in Turkish banking industry. In this sense, the GARCH-type methods with rolling window estimation provide better proxies for market based risk measures since they are able to handle structural change and volatility in the series and to capture the time-varying properties of the series in the presence of clustering of observations. Second, the number of statistically significant independent variables in the market, interest rate and exchange rate beta models change across the whole period, the pre- and the post-crisis periods implying that risk perception of people has changed following the 2008 global financial crisis. Third, the interest rate beta is highly related to accounting variables compared to other risk betas. This implies that accounting variables contain valuable information about interest rate exposure of Turkish banks. Fourth, the results show that exchange rate risk is not an important risk factor for the Turkish banks and it is not associated with a large number of accounting variables of these banks. Fifthly, the diversification (DIV) variable has statistically significant and positive in the pre-crisis period but it has negative sing in the post-crisis period. This indicates that while the market believed that an increase in non-interest income was used for speculation in the pre-crisis period, it sees an increase in non-interest income to be used in risk hedging in the post-crisis period. Sixthly, 
this study investigated the determinants of market, interest rate and exchange rate risk. The findings presented in this study provide valuable information to bank managers, policy makers, and banking regulation and supervision agencies. Seventhly, empirical findings of this paper provide additional evidence to the argument that the 2008 global financial crisis has radically changed the risk perception of the people and the structure of international markets radically. In this sense, the empirical studies on the subject should use methodologies to handle the time varying nature of risk data, structural change and changing coefficients problems. Lastly, this study analysed the data only from seven commercial banks in Turkey due to data availability. The return of a research that extends the methodology used in this study to a large number of banks will be very high.

\section{References}

Agrawal, T. J., \& Sehgal, S. (2018). Dynamic interaction of bank risk exposures: An empirical study for the Indian banking industry. IMM Kozhikode Society \& Management Review, 7(2), 132-153.

Arabacı, H. (2018). Türkiye'de bankacılık sektörünün gelişimi (2000-2016). Meriç Uluslararası Sosyal ve Stratejik Araştırmalar Dergisi, 2 (3), 25-42.

Arora, A. (2012). The impact of size on credit risk management strategies in commercial banks: Empirical evidence from India. The IUP Journal of Financial Risk Management, 9(3), 24-44.

Arora, A. (2013). Credit risk management operations and systems: Does ownership matter?. IIMS Journal of Management Science, 4(1), 77-87.

Au Yong, H. H., Faff, R., \& Chalmers, K. (2009). Derivative activities and Asia-Pacific banks' interest rate and exchange rate exposures. Journal of International Financial Markets, Institutions and Money, 19(1), 16-32.

Bae, K. H., Chan, K., \& Ng, A. (2004). Investibility and return volatility. Journal of Financial Economics, 71, 239-63.

Bae, S. C. (1990). Interest rate changes and common stock returns of financial institutions: Revisited. Journal of Financial Research, 13, 71-79.

Berkowitz, M. K. (1998). Estimating the market risk for nontraded securities: An application to Canadian public utilities. International Review of Financial Analysis, 7(2), 171-179.

Çelik, İ. E. (2019). Assessing the impact of bank risk factors on Turkish bank's stock returns using the Egarch-M Model. Üçüncü Sektör Sosyal Ekonomi Dergisi, 54(2), 811-827.

Choi, J. J., Elyasiani, E., \& Kopecky, K. J. (1992). The sensitivity of bank stock returns to market, interest and exchange rate risks. Journal of Banking \& Finance, 16(5), 983-1004.

Çiçek, M. (2014). Türkiye'de faiz, döviz ve borsa: Fiyat ve oynaklık yayılma etkileri. Ankara Üniversitesi SBF Dergisi, 65(2), 1-28.

Cordella, T., \& Ospino Rojas, A., (2017). Financial globalization and market volatility an empirical appraisal. World Bank Group, Policy Research Working Paper 8091.

Ekinci, A. (2016). The effect of credit and market risk on bank perforamance: Evidence from Turkey. International Journal of Economics and Financial Issues, 6(2), 427-434.

Elyasiani,E., \& Mansur,I. (2005). The association between market and exchange rate risks and accounting variables: A GARCH model of the Japanese banking institutions. Review of Quantitative Finance and Accounting, 25(2), 183-206.

Elyasiani, E., \& Mansur, I. (1998). Sensitivity of bank stock returns distribution to changes in the level of volatility of interest rate: A GARCH-M model. Journal of Banking and Finance, 22, 535-563. 
Elyasiani, E., \& Mansur, I. (2003). International spillover of risk and return among major banking institutions: A bivariate GARCH model. Journal of Accounting, Auditing and Finance, 18(2), 303-330.

Elyasiani, E., Mehdian, S., \& Rezvanian, R. (1994). An empirical test of the association between production and financial performance: The case of the commercial banking industry. Applied Financial Economics, 4, 55- 59.

Er, H., \& Kaya, I. (2012). The relationship between accounting beta and CAPM. 4(2), 233-243.

Ercan, M.K.,Öztürk, B.M., Küçükkaplan,İ., \& Başçı,E.S.(2007). Halka açık firmaların beta katsayılarının regreson modeli ile tespiti ve halka açı olmayan firmalara yönelik uygulanabilirliği. Dokuz Eylïl Üniversitesi İ̈BF Fakülte Dergisi, 22(2), 295-324.

Eryiğit, C., \& Eryiğit, M. (2009). Temel finansal oranların sistematik riske etkisi. İktisat Issletme ve Finans, 24(281), 60-76.

Esqueda, O. A., Assefa, T. A., \& Mollick, A.V. (2012). Financial globalization and stock market risk. Journal of International Financial Markets, Institutions and Money, 22, 87-102.

Fama, E., \& French, K. (1992). The cross-section of expected stock returns. Journal of Finance, 47, 427,465 .

Hassan, M. K. (1993). The off-balance sheet banking risk of large U.S. commercial banks. Quarterly Review of Economics and Finance, 33, 51-69.

Jahankhani, A., \& Lynge, M. (1980). Commercial bank financial policies and their impact on marketdetermined measures of risk. Journal of Bank Research, 11, 169-178.

Karakus, R. (2017). Determinants of affecting level from systematic risk: Evidence from BIST 100 companies in Turkey. Eurasian Journal of Business and Economics, 10(20), 33-46.

Kasman, S., Vardar, G., \& Tunç, G. (2011). The impact of interest rate and exchange rate volatility on bank's stock returns and volatility: Evidence from Turkey. Economic Modelling, 28, 1328-1334.

Kose, M. A., Prasad, E. S., \& Terrones, M. E. (2009). Does financial globalization promote risk sharing?. Journal of Development Economics, 89, 258-70.

Mansur, I., \& Elyasiani, E. (1995). Sensitivity of bank equity returns to the level and volatility of interest rates. Managerial Finance, 21, 58-77.

Mansur, I., Zangeneh, H., \& Zitz, M. S. (1993). The association between banks' performance ratios and market determined measures of risk. Applied Economics, 25, 1503-1510.

McAnally, M. L. (1996). Bank, risk, and FAS105 disclosures. Journal of Accounting, Auditing \& Finance, 453-490.

Mensah, Y.M. (1992). Adjusted accounting beta, operating leverage and financial leverage as determinants of market beta: A synthesis and empirical evaluation. Review of Quantitative Finance and Accounting, 2(2), 187-203.

Schlueter, T., \& Sievers, S. (2014). Determinants of market beta: The impacts of firmspecific accounting figures and market conditions. Review of Quantitative Finance and Accounting, 42(3), 535-570.

Sehgal, S., Agrawal, T. J. (2017). Bank risk factors and changing risk exposures in the pre- and postfinancial crisis periods: An empirical study for India. Management and Labour Studies, 42(4), 356-378.

Stiglitz, J.E. (2004). Capital-market liberalization, globalization, and the IMF. Oxford Review of Economic Policy, 20, 57-71.

Sukcharoensin, P. (2013). Time-varying market, interest rate and exchange rate risks of Thai commercial banks. Asian Academy of Management Journal of Accounting and Finance, 9(1), 25-45. 
Tanrı̈ven, C., \& Aksoy, E. E. (2011). Sistematik riskin belirleyicileri: IMMKB'de sektörel karşılaştırma. MUFAD, Muhasebe Finans Dergisi, 51, 119-138.

Tepeli, Y. (2017) Halka açık olmayan anonim şirketlerde sistematik risk ölçütü beta katsayısının tahmin edilmesi: Turizm sektörü uygulaması. MUFAD Muhasebe Finansman Dergisi, 75, 155-170.

Topak, M. S., \& Talu, N. H. (2017), Bank specific and Macroeconomic determinants of bank profitability: Evidence from Turkey. International Journal of Economics and Financial Issues, 7(2), 574-584.

Umutlu, M., Akdeniz, L., \& Altay, S. (2010). The degree of financial liberalization and aggregated stockreturn volatility in emerging markets. Journal of Banking and Finance, 34, 509-21.

Uyar, U., \& Çağlak, E. (2019). Çimento sektörü açısından sistematik risk-finansal oran ilişkisi: Ana çimento üreticisi ülkeler karş1laştırılması. Muhasebe ve Finans Dergisi, 81, 231-248.

Wong, T. C., Wong, J., \& Leung, P. (2009). The foreign exchange exposure of Chinese banks. China Economic Review, 20(2), 174-182. 


\section{Appendix}

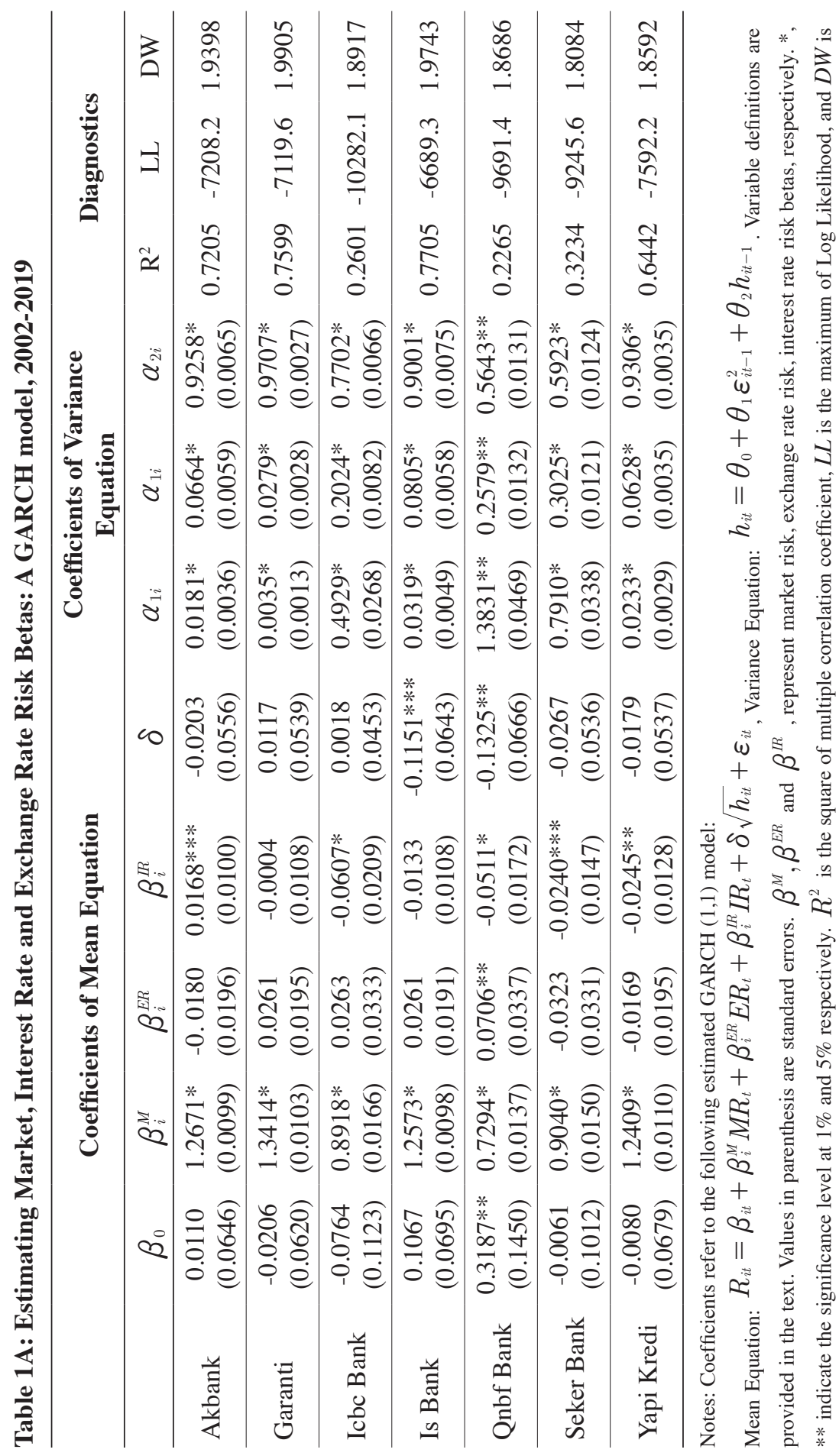




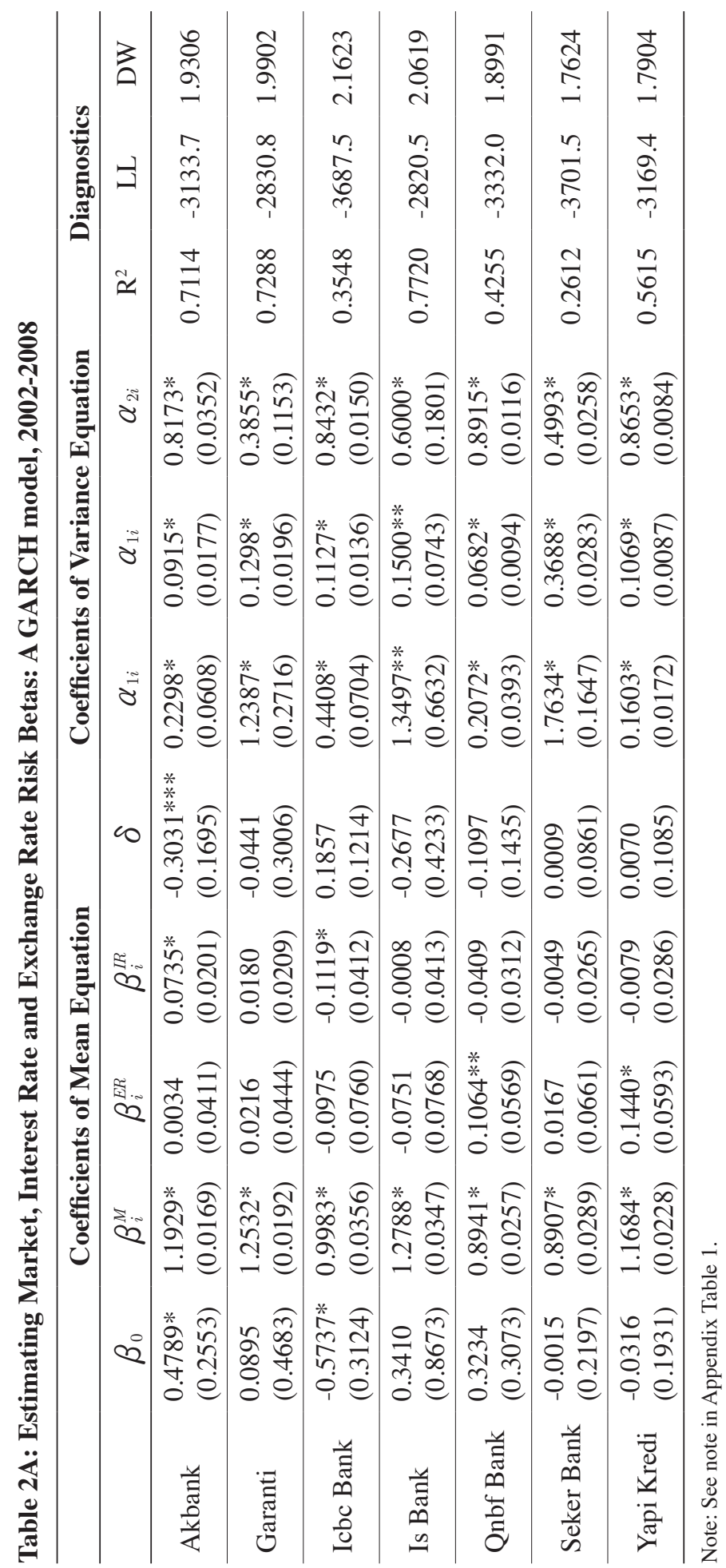




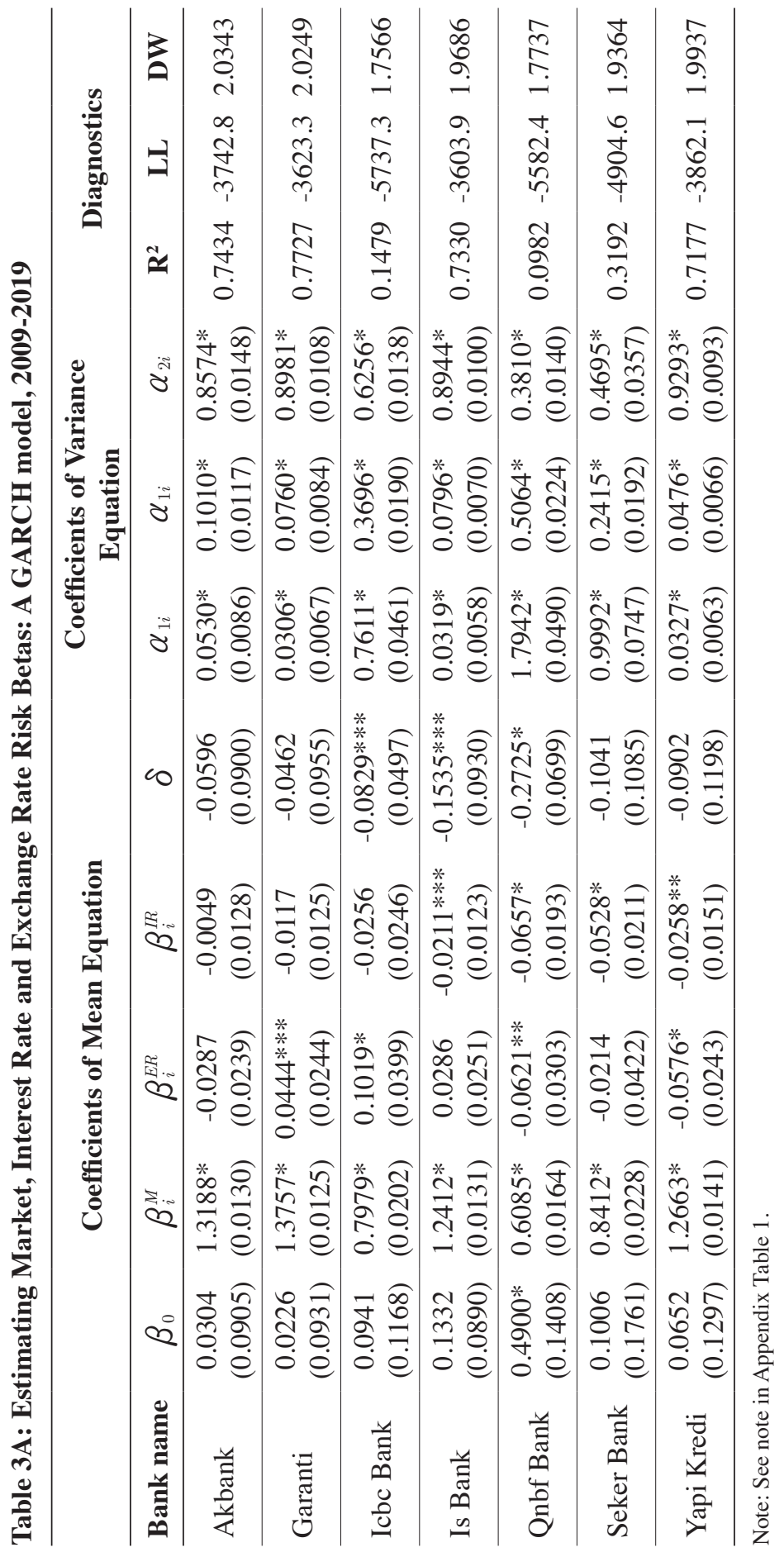

